\title{
A Report of Testing at Archaeological Sites 41FY421, 41FY422, 41FY424 in Fayette County, Texas
}

Glenn T. Goode

Follow this and additional works at: https://scholarworks.sfasu.edu/ita

Part of the American Material Culture Commons, Archaeological Anthropology Commons, Environmental Studies Commons, Other American Studies Commons, Other Arts and Humanities Commons, Other History of Art, Architecture, and Archaeology Commons, and the United States History Commons

Tell us how this article helped you.

This Article is brought to you for free and open access by the Center for Regional Heritage Research at SFA ScholarWorks. It has been accepted for inclusion in Index of Texas Archaeology: Open Access Gray Literature from the Lone Star State by an authorized editor of SFA ScholarWorks. For more information, please contact cdsscholarworks@sfasu.edu. 


\section{A Report of Testing at Archaeological Sites 41FY421, 41FY422, 41FY424 in Fayette County, Texas}

\section{Licensing Statement}

This is a work produced for the Texas Department of Transportation (TxDOT) by the report producer. TxDOT and the report producer jointly own all rights, title, and interest in and to all intellectual property developed under TXDOT's contract with the report producer. The report may be cited and brief passages from this publication may be reproduced without permission provided that credit is given to both TXDOT and the report producer. Permission to reprint an entire chapter, section, figures or tables must be obtained in advance from either the Supervisor of the Archeological Studies Branch, Environmental Affairs Division, Texas Department of Transportation, 125 East 11th Street, Austin, Texas, 78701 or from the report producer. 


\section{A REPORT OF TESTING AT ARCHAEOLOGICAL}

SITES 41FY421, 41FY422, 41FY424 IN FAYETTE COUNTY, TEXAS

BY

Glenn T. Goode

State Department of Highways and Public Transportation Highway Design Division

April 1984 


\begin{abstract}
Sites 41FY421, 41FY 422, and 41FY 424 are upland aboriginal sites situated on divides separating Robinson, Cedar, and Bartons Creeks in northwest Fayette County. These sites are characterized by generally shallow, unstratified sandy deposits. The cultural inventory is limited to stone materials--primarily thermally altered chert and quartzite and lithic debitage. Diagnostic cultural indicators are relatively scarce, with a large majority of these being less than 2000 years in age. One site, 41FY422, produced 25 hearths and related features. Most of these are apparently less than 2000 to 3000 years in age as well.
\end{abstract}




\section{INTRODUCTION}

Archaeological sites 41FY421, 41FY422, and 41FY424 were reported by Glenn T. Goode of the State Department of Highways and Public Transportation (SDHPT) Archaeology Section in February, 1984, and were recommended for test excavations. Testing was conducted by Glenn T. Goode and by one to six members of the local SDHPT office during the period February 9 through March 30, 1984, in accordance with the Procedures for the Protection of Historic and Cultural Properties ( 36 CFR, Part 800). The objective of the tests was to determine elibigility for nomination to the National Register of Historic Places as prescribed by law. 
SITE 41FY421

Site 41FY421 is located on the narrow divide between Cedar and Bartons Creeks, $1 \mathrm{~km}$ west of Cedar Creek and 41FY98. (41FY424 is .5 km eas t of Cedar Creek.)

This open campsite/lithic procurement locus, bisected by State Highway 71, will be completely destroyed by State Highway 71 expansion. The intact portion of the site lies south of the present highway: an area of 55 meters paralleling the roadway and 40 meters along a north-south axis. Evidence of the site exists north of State Highway 71 at a distance of 35 to 45 meters from the south right-of-way. This narrow strip has been thoroughly destroyed by heavy machinery. Along the western margin of the tested area, the surface slopes steeply down to a deep ravine. A narrow strip of the hilltop extending to the south right-of-way fence was created by this ravine and by a more gradual slope along the east and south margins of the site.

Excavation units consist of two 1 by 2 meter units and three 1 by 1 meter units. Three small shovel tests were also dug. All units were excavated in $10 \mathrm{~cm}$ levels with all materials placed in labeled bags.

The soil profile consists of $10 \mathrm{~cm}$ of loamy sand and 20 to $30 \mathrm{~cm}$ of silty sand overlying dense gravel and basal clay. Pebble-size gravel is present throughout the matrix, becoming increasingly abundant with depth.

Site 41FY421 produced a relatively large sample of lithic debitage and abundant thermally altered chert and quartzite. The artifact sample includes numerous cores, hundreds of flakes, several fragments of bifaces broken in manufacture, and at least three roughly trimmed flakes. Diagnostic artifacts are rare, however. The two specimens are a Scallorn arrowpoint and a small, late dart point, resharpened to nearly arrowpoint size.

One hearth feature consisting of burned chert and quartzite was uncovered and recorded. Possibly two hearths were present--the later disturbing and intruding into the earlier. Numerous unburned flint artifacts occurring within and atop 


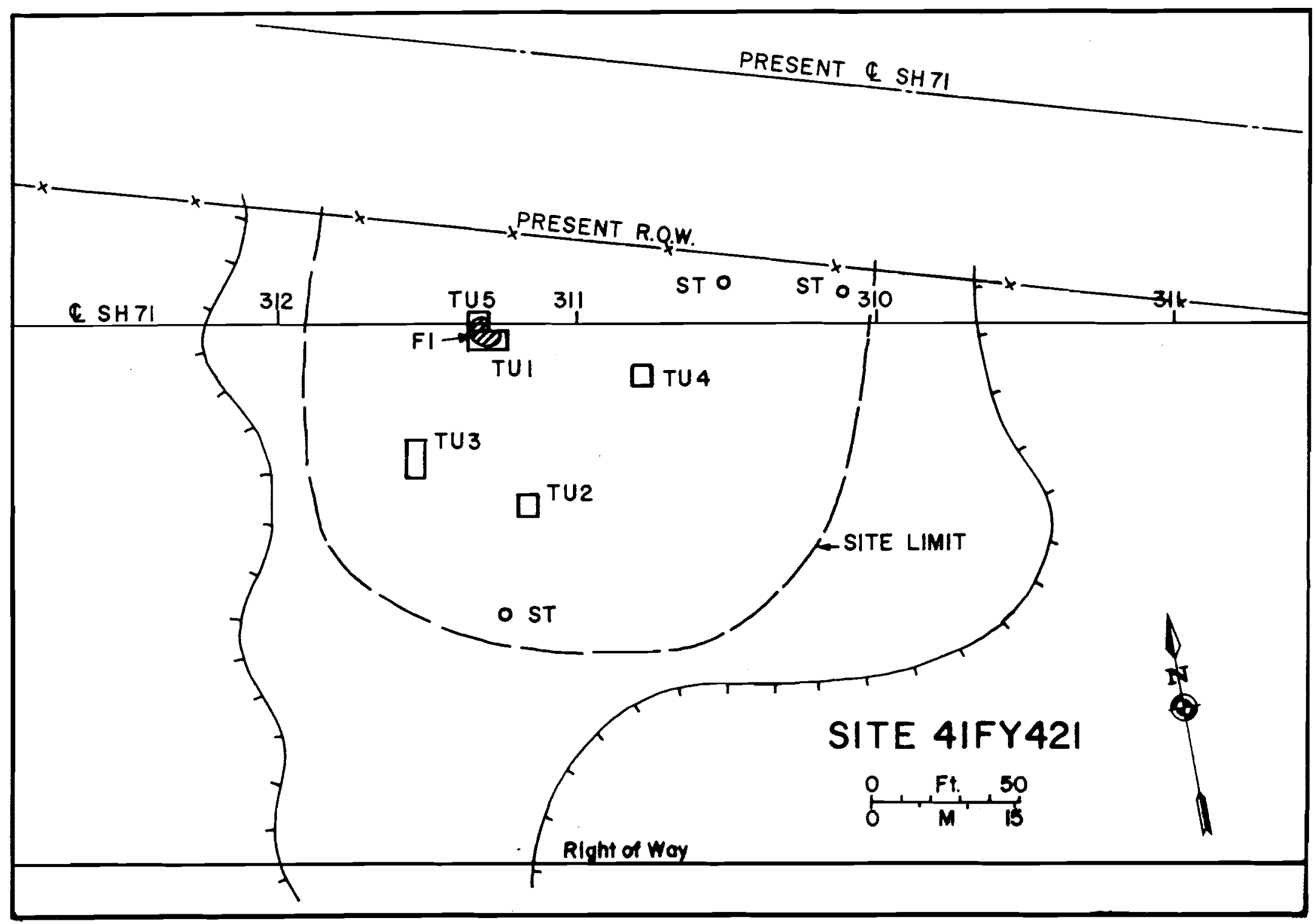

FIGURE 1. Site $41 F Y 421$ site map and excavation unito 
the burned hearthstones suggest continued and rather intensive use of the site. A large amount of material accumulated randomly within the 20 to 30 $\mathrm{cm}$ unstratified deposit.

Site 41FT421 is an upland 1 ithic procurement and campsite. The abundance of cultural material suggest relatively intensive use during an unspecified but perhaps lengthy span of time. Two diagnostic time indicators suggest Transitional Archaic and Late Prehistoric occupations. 


\section{Site Description}

Site 41FY422, the easternmost of the three sites, is located on the divide between Robinson Creek, 500 meters east, and Cedar Creek, 600 meters northwest. The site is 100 to 200 meters south of State Highway 71, 3.1 km west of West Point, Texas.

The site occupies an area of approximately 450 by 150 meters on a broad plateau which is cut by Cedar Creek on the north and dissected by tributaries of Robinson Creek on the east and south. The southern margin of the site is dissected by several deep gullies and slopes sharply down to the nearest water source, a tributary of Robinson Creek.

The right-of-way at 41 FY422 is oriented generally east-west with the long axis (450 meters) of the site following a more east to southwesterly course. The site is bisected by a private road, the east half being designated Area A. Near the south right-of-way fence, several hearths are exposed in the west bank of the road cut. This is Area B. The remainder of the site to the west is Area C.

Much of Area A is forested with various oaks, hickory, cedar, and pine. Yaupon is the most abundant understory vegetation. The northwest portion of Area A, part of Area B, and all of Area C are located within a cleared field which is planted in coastal bermuda.

\section{Excavation Procedures}

Testing at 41FY422 commenced with the placement of randomly located 1 by 2 meter units. Following the initial testing, a grid with primary datum at NO/EO in Area A was established. The east/west baseline (NO/SO) extended to East 63 meters and West 300 meters. Subsequently excavated units were given grid coordinates with the exception of five units in the wooded portion of Area A. 


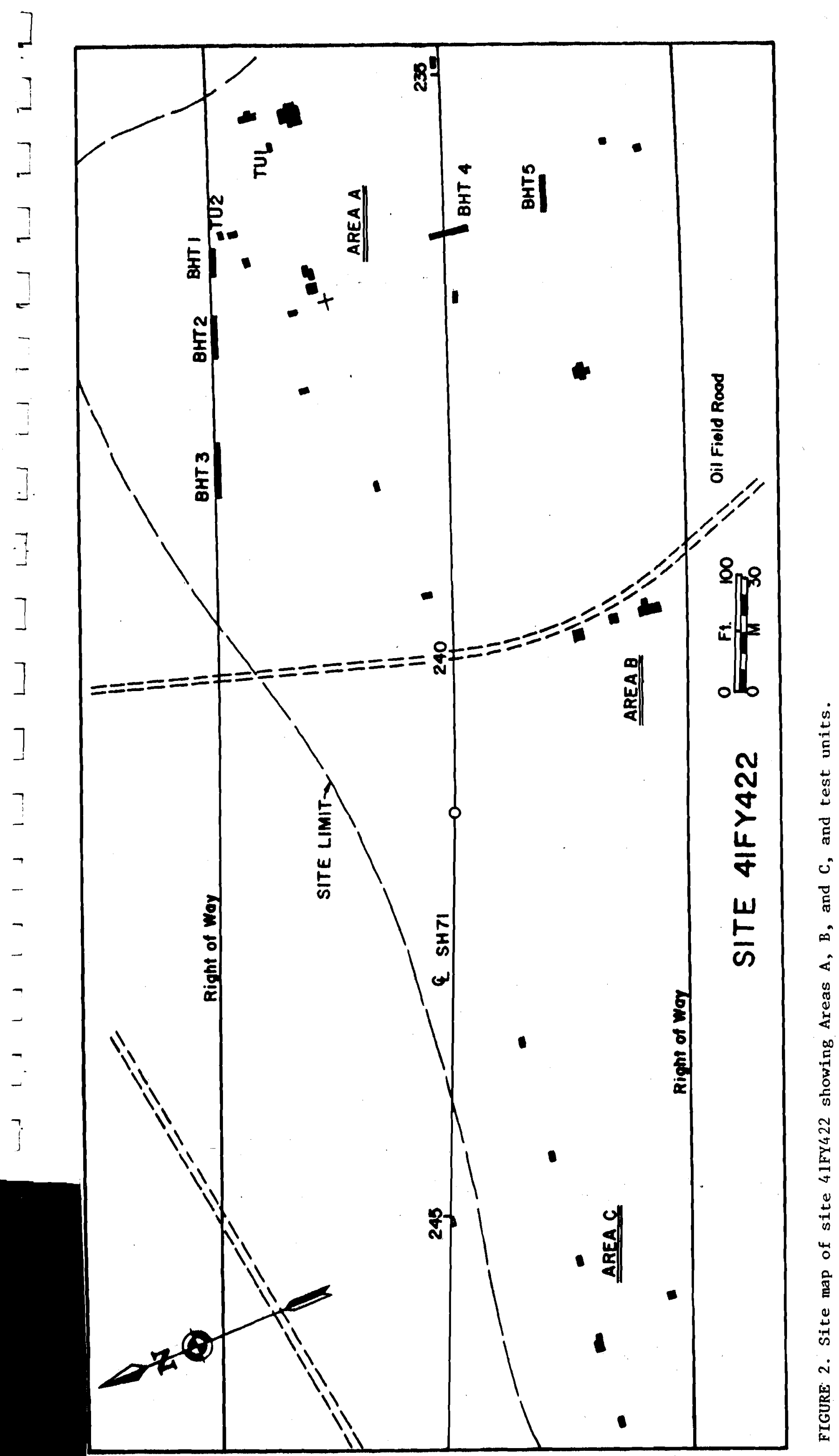


The breakdown of excavated units by size is: 2 by 2 meters $-8 ; 1$ by 2 meters - 31; 1 by 1 meter - 7. Most of these units were excavated to sterile soil. Excavation was by $10 \mathrm{~cm}$ levels, measured from ground level. All matrix was screened through $1 / 4^{\prime \prime}$ hardware cloth and materials bagged accordingly. Burned rock was collected due to difficulties in separating artifacts from burned rock and for measurement of volume. Elevations were recorded with transit and stadia. Similar procedures were followed at Sites $41 \mathrm{FY} 421$ and $41 \mathrm{FY} 424$.

\section{Soil Profiles}

Area A: Soil deposits containing cultural materials range from a maximum of $120 \mathrm{~cm}$ in the central portion to $40 \mathrm{~cm}$ in the southern area near the south right-of-way. Soils in the central area are loamy and silty sands, becoming reddish in color with increased silt and clay content at 40 to $60 \mathrm{~cm}$. Silt and clay content increases gradually with depth, as does small pebble gravel. Compact sandy clay sterile of artifacts occurs at 70 to $120 \mathrm{~cm}$. The silty sand in the southern area contains pebble gravel throughout. The gravel increases with depth until it is quite dense at $40 \mathrm{~cm}$.

Area B: The average depth of culture-bearing matrix in Area B is $40 \mathrm{~cm}$. The light brown silty sand becomes pale brown-white with depth and increased silt content. Pebble gravel is abundant at $40 \mathrm{~cm}$. Sterile, sandy clay occurs below $40 \mathrm{~cm}$.

Area C: Soil ranges from 40 to $90 \mathrm{~cm}$ in depth. Loamy to silty sand becomes more silty at 30 to $50 \mathrm{~cm}$, with a small amount of clay included. The hearth in this area occurs in a pale gray-brown silty matrix at 70 to $80 \mathrm{~cm}$, overlying a reddish brown sandy clay. Sterile sandy clay occurs at a depth of 40 to $90 \mathrm{~cm}$.

\section{Features}

Twenty-five features were recorded at 41FY422. These include one basin hearth, two large flat hearths with small pits beneath the hearths, and a cluster of 
hearths: two of 1.5 meter size with four .5 meter hearths in close association. The remainder are flat hearths of one to three rocks in thickness. More than half of these hearths are disturbed to some degree, some extensively.

Dating these features confidently will be difficult in many cases. Datable materials are lacking for the most part. Tiny charcoal samples were found with only three features. Diagnostic projectile points occurred in the same level in only four cases, and none in direct association with a feature.

The basin hearth in Level 2, Area A, is probably the latest recorded, perhaps of Scallorn age. The scattered flat hearth in Level 10, Area A, was beneath a Pedernales point in Level 9. This perhaps indicates the latest possible age of this feature.

Elsewhere in Area A, Scallorn, Darl, and Late Archaic age projectile points are mixed throughout the upper $50 \mathrm{~cm}$ which contain most of the hearths, making conclusions difficult at this time. One unit produced a Scallorn in Level 5 and an Angostura in Level 6--both probably out of context.

\section{Cultural Inventory}

Typical of many sites in the region, 41FY422 yielded only stone materials. Also typical of regional sites, diagnostic artifacts are not abundant but a relatively large sample of lithic debitage was collected.

Cores and fragments in a 11 stages of reduction are fairly numerous. These exhibit the random reduction strategy typical of regional assemblages. Raw materials are rounded, cobble size chert and quartzite nodules occurring in abundance along margins of hilltops and in streambeds, Petrified wood and ferruginous sandstone are present in small percentages as debitage or hearthstones. Petrified wood occurs abundantly as huge $\log s$ in the area, but little is of tool-making quality.

Flake debitage indicates that all stages of core and biface reduction were practiced. Bifaces broken in manufacture are present in small numbers, and 
FIGURE 3

·

]

]

]

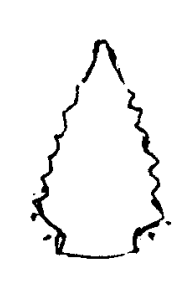

A

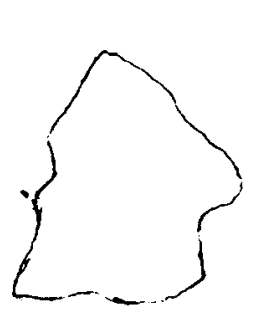

B

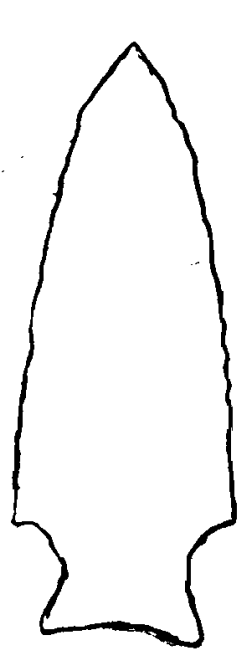

C

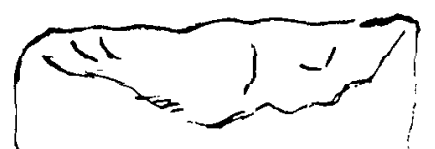

]

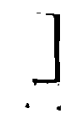

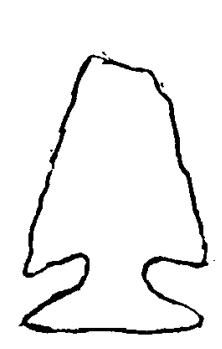

$\mathrm{H}$

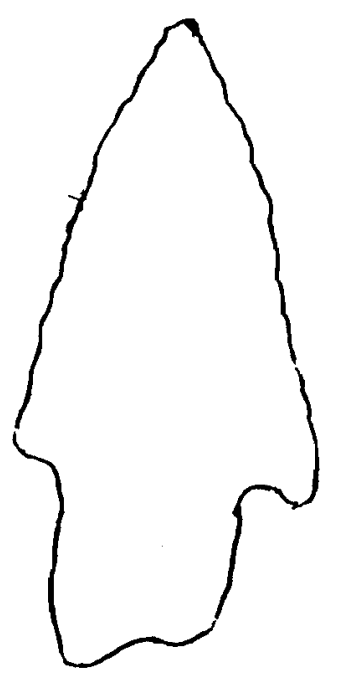

D

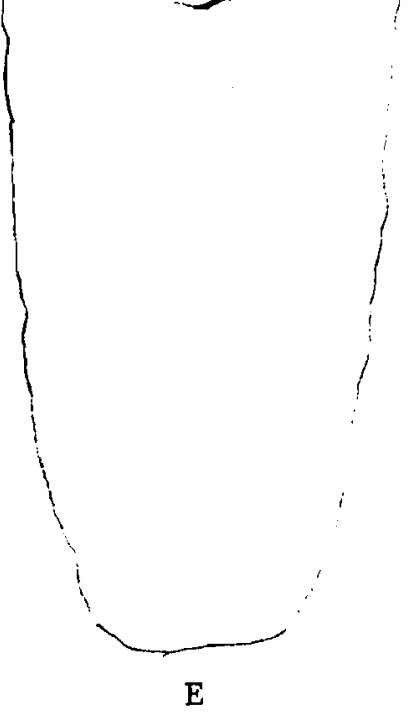

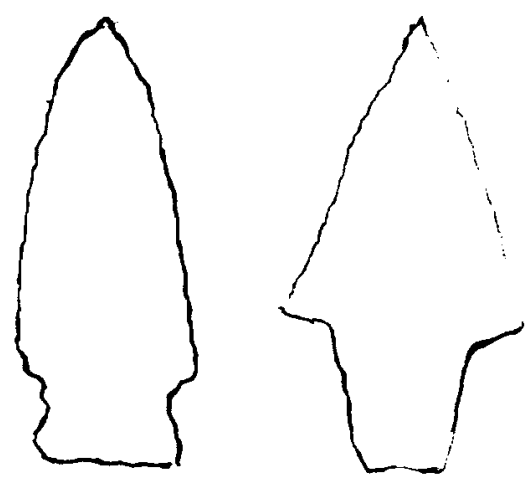

$\mathrm{K}$

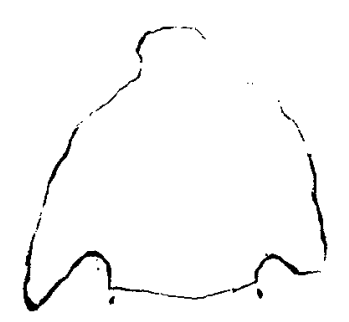

L

]

]
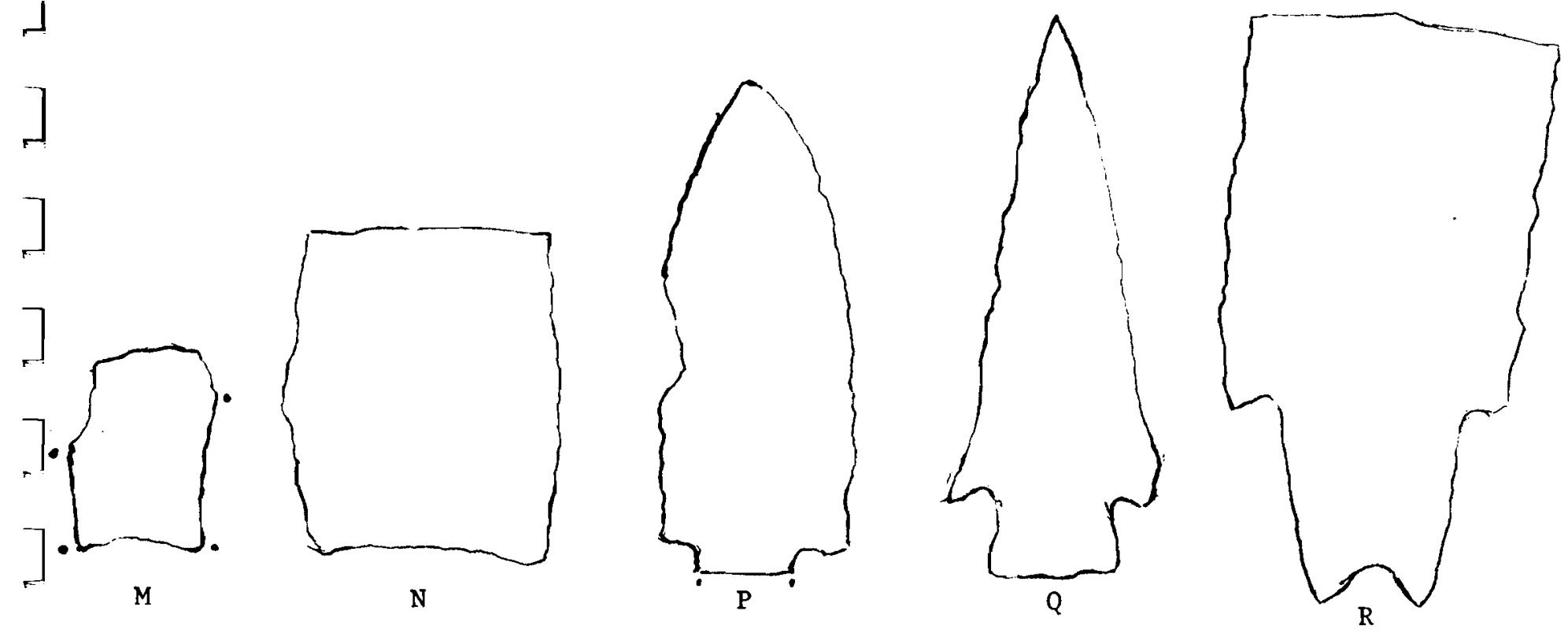

A rtifacts from Site 41FY422. A-E, Area B; F-R, Area A. 
are mostly of relatively small size. This fact is attributable to the small size of raw materials.

In contrast to the large debitage sample, the recognized tool inventory is quite small. Included in the tool categories are about 20 projectile points/ fragments (16 depicted in Fig. 4), several small bifacial knives, rare trimmed flakes, several hammerstones, 1 bifacial gouge, and 1 mano.

The projectile points include 1 Angostura fragment, 2 Pedernales, 2 Late Archaic San Marcos fragments, 2 contracting stemmed points, several Darl-like points, 2 Fairland-like points, and 4 Scallorn. A large majority of these specimens are relatively late, duplicating the pattern observed at $41 F Y 98$. 
SITE $41 F Y 424$

Approximately 50 meters beyond the western margin of 41FY422, dense woods cover the entire right-of-way. These woods extend about 250 meters westward into the area of 41FY424. Another 100 meters westward the plateau narrows and ends abruptly, dissected by deep ravines and a tributary of Cedar Creek. Site $41 F Y 424$ is situated on a narrow extension of the plateau, occupying an area of 100 by 75 meters east to west. The site is bisected by the south right-of-way fence.

Most of the surface and up to $40 \mathrm{~m}$ of the deposit has been obliterated by heavy machinery. South of the right-of-way the site is thoroughly cleared. Within the right-of-way remaining vegetation is primarily post oak and yaupon with scattered pine. Blackjack oak, pin oak, and hickory abound in the area.

Three 1 by 1 meter test units and three shovel tests were excavated. A grid was not established, units being located from the south right-of-way fence.

The soil profile consists of 40 to $50 \mathrm{~cm}$ of loamy and silty sand. Pebble size gravel exists throughout the deposit, becoming more abundant with depth. At 40 to $50 \mathrm{~cm}$ the gravel is dense and the matrix is devoid of cultural materi a 1 .

Site $41 F Y 424$ is the least productive by far of the three sites. Only lithic debitage was found. Included in the small sample are two final-stage bifacial specimens: one broken in manufacture and a thin but incomplete specimen. A few cores were recovered, in conjunction with the relatively small flake sample. Two trimmed flakes are present, but evidence of use is not obvious. One trimmed flake found on the surface is a possible tool. This assemblage suggests 41FY 424 served as a 1 ithic procurement locus, with at least some bifacial reduction to a nearly complete stage.

Thermally altered stone is widespread in moderate amounts but no evidence of intact hearth features was found. 41 FY424 can be classified as an upland resource procurement and campsite, occupied sporadically during an undetermined period of time. 


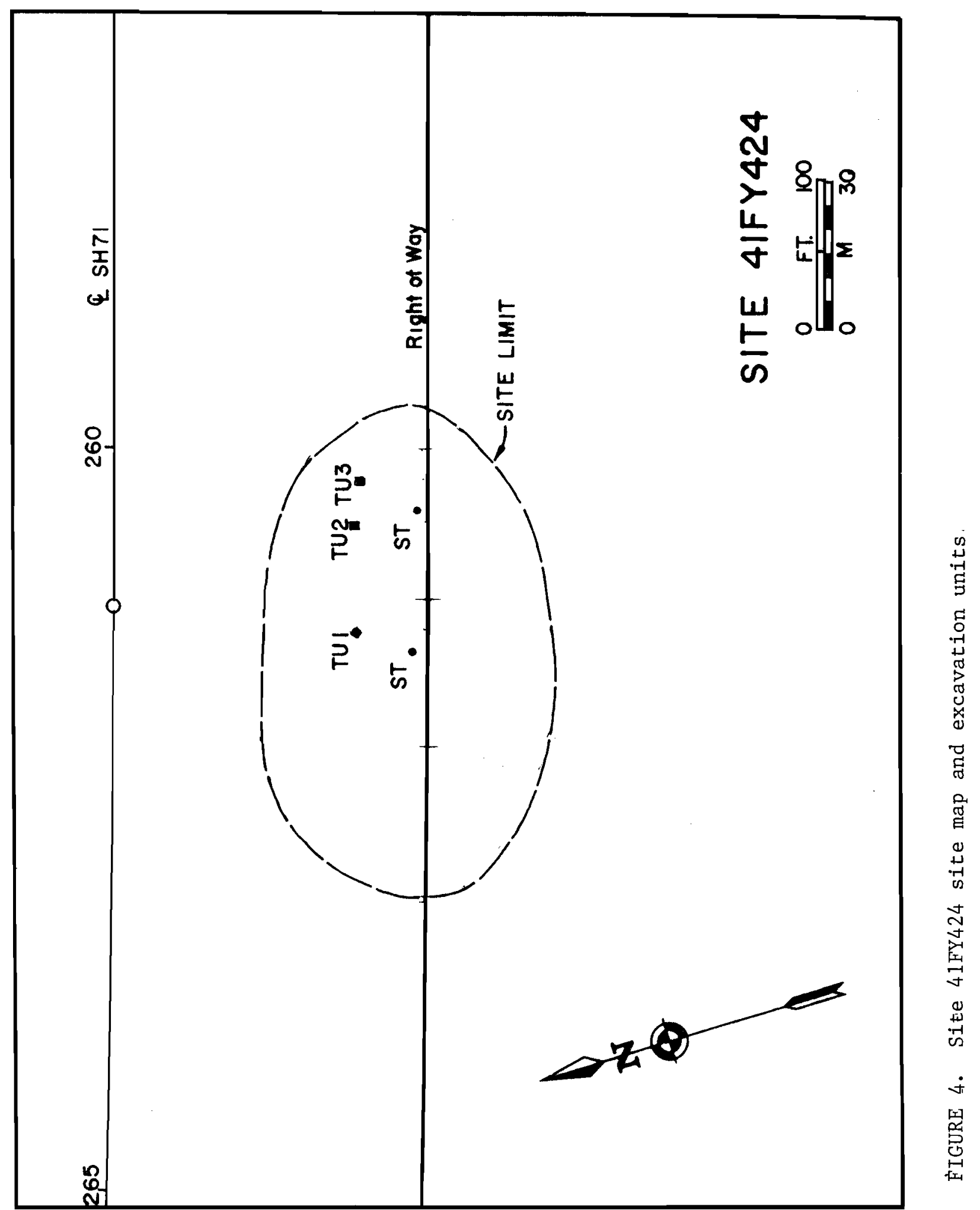


SUMMARY AND RECOMMENDATIONS

Test excavations at three aboriginal sites indicate rather intensive use of upland hills and plateaus in the study area. 41FY422, by far the largest and most important of the three, is a habitation and resource procurement site occupied rather intensively over a period of at least three thousand years. Twenty-five recorded hearths and related features were located throughout the site area. "Groups" of hearths were present in Areas A and B. Unfortunately diagnostic artifacts were not found in the same level as a hearth, and none in direct association. Also, bone and shell were not preserved, and only three hearths had tiny charcoal samples associated.

Disturbance was heavy in all areas of the site. Root and rodent disturbance is considerable throughout. A large majority of the site has been cleared and cultivated. Disturbance from a circa 1920 habitation in Area A was evident to $40 \mathrm{~cm}$ in 8 units, with artifacts scattered through the upper 30 $\mathrm{cm}$.

Area B, with only $40 \mathrm{~cm}$ of deposit, had especially heavy root disturbance. In recent years large trees were bulldozed in constructing a road. At least the upper $10 \mathrm{am}$ was removed, then the surface was packed and covered with road-base material. Base material extends $30 \mathrm{~cm}$ deep into stump and root holes. The Pedernales point from this area occurred in such a disturbance in Level 2.

Area $\mathrm{C}$ is the least productive area of the site, with only one hearth feature, little debitage, and no diagnostics. And Area $C$ has experienced considerable disturbance. In recent years, bulldozing removed a 11 vegetation leaving tremendous root disturbance. Also, an average of $30 \mathrm{~cm}$ of topsoil was removed from most of the area.

Site 41FY 422 produced a large sample of lithic debitage, 25 features, and a small sample of mostly late diagnostic projectile points. It is quite similar to 41FY98, $1 \mathrm{~km}$ to the west, in these respects. Tools other than projectile 
points are also rare. Diagnostics were not found with features and charcoal was rare as well. It is felt that an adequate sample of this site has been collected and that further work would prove repetitious and unproductive.

Sites 41FY421 and 41FY424 are shallow, unstratified upland camps/quarries which produced a very limited amount of significant cultural material. Diagnostics and features are rare and disturbance and mixing in the shallow deposits is substantial.

In view of these findings, archaeological sites 41FY421, 41FY422, and 41FY424 are not recommended for further testing and are considered ineligible for inclusion in the National Register of Historic Places. 